\title{
ILEARNING METODE BELAJAR EFEKTIF UNTUK SEKOLAH TINGGI
}

\author{
Dewi Immaniar Desrianti ${ }^{1}$ \\ Untung Rahardja ${ }^{2}$ \\ Rahma Rinie $^{3}$ \\ e-mail: dewi.immaniar@raharja.info; untung@raharja.info; rahma.rinie@raharja.info
}

Diterima : 19 Nopember 2013 / Disetujui : 26 Desember 2013

\begin{abstract}
Science advancement of information technology is rapidly increasing to support technology development in education today it is as seen from technology trends of internet has evolved. The first time website only adopted information needs first step. Internet development may made web to web interaction. This interaction can share information, document, picture, video format, this bring the impact of social increased in cyberspace and then followed by world of learning but current condition of internet uses is as a self learning method, it's not applied optimally in learning. The worst internet system only focused on the process of sending e-mail message from educators for students, not offering on independent approach and interactive learning experience. By using iLearning enable the learning process in an interactive self learning is applied in the realization and not separate from daily life. This article will explain to learn electronic learning distribution e-learning for iLearning, identify problem, encountered especially in education with an internet technology, iLearning architecture, iLearning design, weakness and excess iLearning, iLearning implementation in learning and interaction in daily activity in 4B ( learn, pray, work, play) in world of education system iLearning is adopted from e-learning education, that cannot be separated from learning activity at daily life and iLearning contribution really help independently learn need, which all knowledgement is in our hand. iLearning contained in this article may create a self-learning interactive in everyday life. iLearning organize all learners activities continually by learning, playing, working, and praying. iLearning development can create a good integrity to the system of modern learning in the future. So ilearning is the good leaders for both either educators or learners to get accurate information and
\end{abstract}

1. Dosen Jurusan Sistem Informasi, STMIK Raharja

Jl. Jend Sudirman No. 40 Modern Cikokol-Tangerang Telp. 5529692

2. Dosen Jurusan Sistem Informasi, STMIK Raharja

Jl. Jend Sudirman No. 40 Modern Cikokol-Tangerang Telp. 5529692

3. Mahasiswa Jurusan Sistem Informasi, STMIK Raharja

Jl. Jend Sudirman No. 40 Modern Cikokol-Tangerang Telp. 5529692 
which can be relavant in anywhere, anytime when we learn, play, pray, and work. $4 b$ do with just one touch of the hand

Keywords: iLearning, independent learning, modern learning, interactive.

\begin{abstract}
ABSTRAKSI
Kemajuan ilmu teknologi informasi pertumbuhan IPTEK yang semakin pesat mendorong perkembangan teknologi dalam bidang pendidikan saat ini seperti yang terlihat dari tren teknologi bahwa teknologi internet telah berevolusi. Pada awalnya website hanya mengadopsi kebutuhan informasi. Langkah awalnya perkembangan internet memungkinkan dapat interaksi antar web ke web, jenis interaksi ini dapat sharing informasi dalam bentuk dokumen, gambar, atau video. Hal ini membawa dampak peningkatan sosial di dunia maya (internet) yang kemudian diikuti oleh dunia pembelajaran. Namun kondisi saat ini pemanfaatan internet sebagai metode belajar mandiri tidak diterapkan secara maksimal dalam pembelajaran. Yang terburuk sistem internet hanya difokuskan pada proses pengiriman pesan e-mail pelajar kepada pendidik dan tidak menawarkan pendekatan dan pengalaman mandiri belajar interaktif. Dengan menggunakan iLearning memungkinkan proses belajar mengajar mandiri secara interaktif diterapkan dalam pembelajaran dan tidak terpisah dari realisasi kehidupan sehari-hari. Dalam artikel ini akan dijelaskan mengenai pembelajaran electronic learning (e-learning), distribusi e-learning untuk iLearning, diidentifikasikan masalah yang dihadapi khususnya dalam suatu pendidikan dengan teknologi internet, arsitektur iLearning, iLearning system design, kelemahan dan kelebihan iLearning, implementasi iLearning dalam belajar dan interaksi di kehidupan sehari-hari dalam 4B (Belajar, Berdoa, Bekerja, dan Bermain). Dalam dunia pendidikan sistem iLearning merupakan adaptasi dari pendidikan electronic learning yang tidak terpisahkan kegiatan pembelajaran dengan kehidupan sehari-hari dan kontribusi iLearning sangat membantu kebutuhan belajar mandiri dimana semua pengetahuan ada dalam genggaman tangan. iLearning yang terdapat pada artikel ini dapat menciptakan pembelajaran yang mandiri dan interaktif dalam kehidupan sehari-hari. iLearning mengorganisir aktifitas peserta didik untuk bisa berkesinambungan dengan belajar, bermain, bekerja, dan berdoa. Pengembangan iLearning dapat menciptakan integritas yang baik untuk sistem pembelajaran modern di masa depan. Dengan demikian iLearning merupakan leaders yang baik untuk pendidik maupun peserta didik untuk mendapatkan informasi yang akurat dan relavant yang bisa di dapat dimana saja, kapan saja disaat kita belajar, bermain, berdoa maupun bekerja. Melakukan 4B hanya dengan satu sentuhan tangan.
\end{abstract}

Keyword: iLearning, pembelajaran mandiri, pembelajaran modern, interaktif. 


\section{PENDAHULUAN}

Sejalan dengan dimulainya era teknologi saat ini, memasuki era perubahan dengan penerapan teknologi diberbagai bidang yang telah menciptakan berbagai macam perubahan dalam segala aspek kehidupan. Telah diketahui kemajuan suatu bangsa salah satu indikatornya dapat dilihat dari perkembangan dunia pendidikan menggambarkan tingkat tingginya kebudayaan suatu bangsa. Kemajuan pendidikan akan berpengaruh secara signifikan terhadap kemajuan suatu bangsa. Selain itu pendidikan tidak terlepas dalam kehidupan sehari-hari.

Di dunia pendidikan saat ini selalu mengalami perubahan kemajuan dalam proses pembelajaran, sistem yang selama ini sudah ada dianggap kurang sesuai lagi dengan perkembangan saat ini.Dengan adanya sistem informasi yang canggih disegala bidang, termasuk dalam hal pendidikan sebagai upaya peningkatan prestasi belajar mahasiswa, selain itu dapat meningkatkan kualitas pembelajaran yang terus dilakukan oleh lembaga pendidikan tinggi. Dunia pendidikan harus memiliki suatu metode yang dapat membantu peserta didik untuk mempermudah proses belajar dan mengajaryang lebih efektif.

Skenario mengajar dan belajar perlu disiapkan secara matang dalam sebuah kurikulum pembelajaran untuk meningkatkan standart mutu pendidikan, upaya penerapan teknologi khususnya teknologi informasi komunikasi di bidang pendidikan contohnya adalah metode belajar dan mengajar dengan menggunakan internet. Internet, merupakan suatu bentuk kemajuan teknologi yang sedang banyak digandrungi pada saat ini. Kurang maksimalnya penggunaan fasilitas internet mendorong lahirnya suatu desain pembelajaran yang mampu melebihi pembelajaran yang ada saat ini. Dengan internet semua akses dapat dicapai dengan mudah, melalui internet diharapkan proses belajar mengajar dapat dilaksanakan lebih mudah, cepat, efisien, dan efektif. Suatu institusi pendidikan sekarang telah banyak yang menerapkan internet untuk media belajar mengajar.

Siahaan (2002:6) berpendapat media internet yang difokuskan untuk pendidikan sering kita sebut e-learning. Istilah e-learning ini muncul dengan seiring perkembangan kemajuan dunia elektronik dan pemanfaatannya dalam kehidupan manusia sekarang ini, teknologi internet dan teknologi berbasiskan komputer sebagai alat pengolah data dan informasi. Istilah e-learning sudah ada sekitar tahun 1970 yang merupakan penyampaian komunikasi pendidikan dan pelatihan secara online. 
Pengembangan pendidikan menuju e-learning merupakan suatu alternatif dalam meningkatkan standar mutu pendidikan, karena e-learning merupakan satu penggunaan teknologi internet dalam penyampaian pembelajaran dengan jangkauan luas dan berlandaskan tiga kriteria yaitu: (1) e-learning merupakan jaringan dengan kemampuan untuk memperbaharui, menyimpan, mendistribusi dan membagi materi ajar atau informasi, (2) pengiriman sampai ke pengguna terakhir melalui komputer dengan menggunakan teknologi internet yang standar, (3) memfokuskan pada pandangan yang paling luas tentang pembelajaran di balik paradigma pembelajaran tradisional (Rosenberg 2001; 28).

E-Learning merupakan aplikasi teknologi informasi dalam pembelajaran yang teknologi utamanya adalah teknologi komputer, multimedia dan teknologi komunikasi modern yang lain.Untuk itu, e-learning merupakan langkah praktis dan efisien yang dilakukan banyak kalangan saat ini. Bagi instansi pendidikan kualitas belajar dan mengajar merupakan suatu yang utama dimana teknologi informasi dan komunikasi juga harus tepat pemanfaatannya. Penggunaan e-learning pada dasarnya adalah cara paling efektif dalam pendidikan karena telah berbasis online namun dalam pemanfaatan e-learning diperlukan pertimbangan yang matang, sehingga dapat memberikan manfaat untuk peningkatan kualitas hasil belajar dan apakah pendidikan yang diharapkan yaitu yang berkualitas, prinsipnya tidak terlepas dari kehidupan seharihari dan belajar mandiri interaktif terserap maksimal untuk pembelajaran.

\section{PERMASALAHAN}

Salah satu model pembelajaran yang masih berlaku dan sangat banyak digunakan oleh pengajar adalah model pembelajaran konvensional. Pembelajaran konvesional. Pembelajaran konvensional mempunyai beberapa pengertian menurut para ahli, diantaranya:

Freire (1999), memberikan istilah terhadap pengajaran seperti itu sebagai suatu penyelenggaraan pendidikan ber "gaya bank" penyelenggaraan pendidikan hanya dipandang sebagai suatu aktivitas pemberian informasi yang harus “ditelan” oleh pelajar, yang wajib diingat dan dihafal.

Menurut Ujang Sukandi (Kholik, 2011) mendefenisikan bahwa pembelajaran konvensional ditandai dengan guru mengajar lebih banyak mengajarkan tentang konsep-konsep bukan kompetensi, tujuannya adalah siswa mengetahui sesuatu bukan 
mampu untuk melakukan sesuatu, dan pada saat proses pembelajaran siswa lebih banyak mendengarkan. Disini terlihat bahwa pembelajaran konvensional yang dimaksud adalah pembelajaran yang lebih banyak didominasi gurunya sebagai “pentransfer” ilmu, sementara siswa lebih pasif sebagai “penerima” ilmu.

Dan menurut Djamarah (1996), metode pembelajaran konvensional adalah metode pembelajaran tradisional atau disebut juga dengan metode ceramah, karena sejak dulu metode ini telah dipergunakan sebagai alat komunikasi lisan antara guru dengan anak didik dalam proses belajar dan pembelajaran. Dalam pembelajaran sejarah metode konvensional ditandai dengan ceramah yang diiringi dengan penjelasan, serta pembagian tugas dan latihan.

Secara umum ciri-ciri pembelajaran menggunakan metode konvensional yaitu mahsiswa menjadi penerima informasi secara pasif, dimana mahasiswa mendapatkan informasi dari dosen dan pengetahuan diasumsinya sebagai badan dari informasi dan keterampilan yang dimiliki sesuai dengan standar, proses belajar secara individual, penilaian bersifat sporadis, pembelajaran yang dilakukan secara abstrak dan teoritis,perilaku dibangun atas kebiasaan, perilaku berdasarkan motivasi ekstrinsik, dosen sering bertindak memperhatikan proses kelompok yang terjadi dalam kelompok-kelompok belajar, tidak ada kelompok-kelompok kooperatif dosen sebagai penentu jalannya proses belajar mengajar, dan interaksi diantara mahasiswa kurang.

Selama ini metode pengajaran yang diberikan dosen masih menggunakan pendekatan konvensional dengan metode pengajaran repetisi atau pengulangan. Metode ini alhasil menyebabkan pendidikan dan penguasaan materi yang diajarkan kurang maksimal dan peserta didik juga kurang bisa berfikir kritis. Untuk e-learning memiliki keunggulan lebih untuk saat ini. Namun diantara keunggulan itu, e-learning memiliki sistem pendidikan yang masih terpisah dari realisasi kehidupan sehari-hari yang harusnya bisa menjadi media belajar mandiri interaktif. Berikut disampaikan tampilan pembelajaran e-learning yang masih terpisah dari realisasi kehidupan sehari hari. 


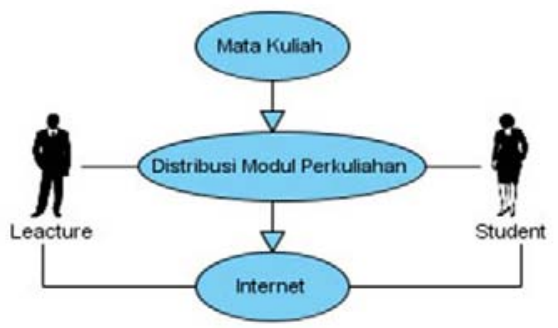

\section{Diagram 1. Use Case Education of E-Learning}

Dari diagram 1 diatas, bisa dilihat untuk belajar dan mengajar masih bersifat konvensional. Internet yang digunakan hanya untuk pendistribusian modul perkuliahan pengajar. Kelemahan dari sistem internet adalah hanya difokuskan pada proses pengiriman pesan e-mail pelajar kepada pendidik dan tidak menawarkan pendekatan dan pengalaman mandiri belajar interaktif.

Untuk itu ada tiga kerugian yang akan dihadapi yaitu: 1) kurangnya semangat pelajar dalam belajar; 2) tidak praktis dalam media pembelajaran misalnya e-learning masih memerlukan buku sebagai bahan pembelajaran; dan 3) realisasi belajar masih terpisah dari kehidupan sehari-hari.

\section{LITERATURE REVIEW}

Banyak penelitian yang sebelumnya dilakukan berkenaan dengan Literature Integrasi penyampaian metode pembelajaran dalam upaya penyampaian pengembangan pembelajaran. Hal ini perlu dilakukan studi pustaka sebagai salah satu metode penelitian yang akan dilakukan. Diantaranya adalah mengidentifikasi metode yang pernah dilakukan, meneruskan penelitian sebelumnya, serta mengetahui orang lain yang spealisasi dan area penelitian sama di bidang ini. Beberapa Literature Review tersebut adalah sebagai berikut :

1. Penelitian yang telah dilakukan Nurhadi yang berjudul "Pengembangan Elearning Pembelajaran Pendidikan Kewarganegaraan untuk Sekolah Lanjutan Tingkat Atas (SLTA)” Penelitian ini bertujuan untuk: (1) menghasilkan elearning pembelajaran PKn untuk SLTA(eCivics) dengan spesifikasi bentuk dan isi yang telah ditetapkan, (2) mengetahui kualitas kelayakan eCivics sebagai media pembelajaran, dan (3) mengetahui efektivitas pembelajaran PKn dengan menggunakan eCivics. Jenis penelitian adalah Penelitian dan Pengembangan 
(R\&D). Hal ini dibuat untuk mengetahui apakah hasil belajar eCivics lebih baik dari penelitian dan pengembangan sebagai media tradisional. Hasil penelitian menunjukkan sebagai berikut. (1) eCivics yang dihasilkan adalah sebuah sistem manajemen pembelajaran (LMS) online yang dibuat dengan software aplikasi moodle. eCivics menyajikan materi-materi pembelajaran Pendidikan Kewarganegaraan, khususnya untuk kelas XI, SK ke-4, KD ke5 beserta tes dan tugas-tugasnya. (2) eCivics layak sebagai media pembelajaran PKn berdasarkan validasi Ahli Media, Ahli Materi, siswa, dan guru dengan skala 5, kelayakannya mencapai rerata skor 4,32 (kategori “sangat baik”).(3) Efektivitas pembelajaran PKn dengan menggunakan eCivics lebih baik daripada Penelitian dan pengembangan berdasarkan reaksi dan sikap siswa terhadap media dan pencapaian hasil belajar siswa: kognitif dan skill kewarganegaraan.[1].

2. Penelitian yang telah dilakukan K. Yuli yang berjudul “ Teknologi Informasi Dan Komunikasi dalam Proses Pembelajaran “. Tujuan penelitian ini adalah menemukan secara luas dan mendalam mengenai pemanfaatan teknologi informasi dan komunikasi, khususnya komputer dengan perangkatnya untuk pembelajaran di sekolah. Sekolah yang menjadi target penelitian adalah SMAK1 dan SMAK7 BPK PENABUR Jakarta. Penelitian ini adalah penelitian kualitatif dengan menggunakan metode studi kasus. Temuan-temuan dalam penelitian ini di indikasikan bahwa ada perbedaan dalam pemanfaatan ICT di SMAK1 dan SMAK7, akses internet di kedua sekolah sangat terbatas, selain guru yang mengembangkan bahan ajar berbasis komputer kedua sekolah membeli program pembelajaran dari toko buku, e-learning umumnya masih bersifat offline, komputer dengan perangkatnya masih sebatas memindahkan bahan ajar ke berbagai aplikasi komputer, kedua sekolah memiliki fasilitas yang lengkap melebihi ketentuan yang ada di Permendiknas No 24 tahun 2007, faktor pendukung lainnya adalah guru- guru memiliki keahlian dibidang TIK, factor penghambat adalah jaringan internet yang sangat lambat, dampak positif bagi siswa adalah siswa dapat belajar dimana saja, merasa senang, lebih tertarik, mudah memahami materi, belajar lebih efisien [2].

3. Penelitian yang telah dilakukan Tafiardi dari Universitas Negeri Jakarta, yang berjudul “Meningkatkan Mutu Pendidikan Melalui E-learning”. Sejalan dengan perkembangan ilmu dan teknologi terutama teknologi informasi, pemanfaatan internet dalam bidang pendidikan terus berkembang. Pemanfaatan internet ini tidak hanya untuk pendidikan jarak jauh, akan tetapi juga dikembangkan dalam sistem pendidikan konvensional. E-learning adalah suatu model pembelajaran yang dibuat dalam format digital melalui perangkat elektronik. Tujuan 
digunakannya e-learning dalam sistem pembelajaran adalah untuk memperluas akses pendidikan ke masyarakat luas [3].

4. Penelitian yang telah dilakukan Y. Rizka UIN SYARIF HIDAYATULLAH yang berjudul “ Perancangan E-learning Berbasis Pakar PHP Dan MYSQL “. E-learning merupakan salah satu media pembelajaran yang memanfaatkan perkembangan teknologi yaitu internet. Konsep e-learning ini membawa pengaruh terjadinya proses transformasi pendidikan konvensional ke dalam bentuk digital, baik secara isi maupun sistemnya. Semua istilah tersebut menyiratkkan pengertian bahwa pelajar terpisah dari pengajar secara jara jauh, pelajar menggunakan teknologi untuk mengakses bahan ajar, pelajar menggunakan teknoogi internet, untuk berinteraksi dengan pengajar dan pelajar lainnya. Andreson dan Elloumi (2004) mendefinisikan e-learning sebagai penggunaan internet untuk mengakses bahan ajar, berinteraksi dengan isi bahan ajar, pengajar dan peserta ajar lainnya, dan mendapatkan bantuan belajar selama proses pembelajaran, untuk dapat memperoleh pengetahuan, mengkonstruksi pemahaman, dan bertumbuh kembang melalui pengalaman belajar [4].

5. Penelitian yang telah dilakukan H. Kuswari Fakultas MIPA Universitas Negeri Yogyakarta, yang berjudul “E-learning Adaptif Berbasis Karakteristik Peserta Didik” Yogyakarta. E-learning adaptif berbasis karakteristik. Perkembangan teknologi komunikasi dan informasi telah mempengaruhi masyarakat, khususnya sistem pendidikan menuju paradigma pembelajaran baru diantaranya adalah dengan proses pembelajaran e-learning. E-learning adalah wujud penerapan teknologi informasi di bidang pendidikan dalam bentuk sekolah maya. Sistem e-learning telah banyak dikembangkan oleh berbagai lembaga pendidikan dan menjadi hal yang sangat penting dalam pelaksanaan pendidikan jarak jauh. Sistem e-learning yang ada sekarang ini umumnya menyajikan presentasi materi pembelajaran yang sama untuk setiap pengguna karena menganggap bahwa karakteristik semua pengguna adalah homogen, padahal dalam kenyataannya setiap peserta didik mempunyai karakteristik yang berbeda dalam belajar, di antaranya adalah gaya belajar, tingkat kematangan, latar belakang dan taraf pengetahuan, prestasi belajar, sehingga perlu digunakan sistem e-learning yang mampu untuk mengakomodasi permasalahan perbedaan karakteristik peserta didik tersebut, yang disebut sebagai e-learning adaptif. Model e-learning adaptif berbasis karakteristik peserta didik adalah AES-CS (Adaptive Educational System base on Cognitive Style), Adaptive e-learning Hypermedia System based on Learning Styles (AEHS-LS) [5] 
6. Penelitian yang telah dilakukan Jacobus Wiwin Kuswinardi Program Studi Manajemen Informatika Fakultas Teknologi Informasi Universitas Kanjuruhan Malang yang berjudul “ Pengembangan Sistem Konten Electronic Book Terpadu Untuk Media Pembelajaran Berbasis Web”. Teknologi informasi banyak berperan untuk kebutuhan sehari-hari, diantaranya kebutuhan pribadi (personal), perusahaan (company), pendidikan (education), dan lain-lain. Pada saat ini mulai terasa dunia pendidikan khususnya telah terjadi pergeseran, dari pendidikan tatap muka yang konvensional ke arah pendidikan yang lebih terbuka (pemanfaatan media internet) yang sering dikenal dengan istilah ELearning (Pembelajaran Secara Elektronik). E-Learning adalah sistem pendidikan yang menggunakan aplikasi elektronik untuk mendukung belajar mengajar dengan media internet, intranet, audio atau tape video, TV satelit, dan CD-ROM. Keuntungan menggunakan elearning diantaranya adalah : (1) menghemat waktu proses belajar mengajar, (2) mengurangi biaya perjalanan, (3) menghemat biaya pendidikan secara keseluruhan (infrastruktur, peralatan, buku), (4) menjangkau wilayah geografis yang lebih luas, (5) melatih pelajar lebih mandiri dalam mendapatkan ilmu pengetahuan (Romi Satria Wahono, 2008). Berdasarkan hal tersebut sangat penting dibangun sebuah sistem konten electronic-book terpadu berbasis web untuk media pembelajaran dengan menggunakan media internet [6].

7. Penelitian yang telah dilakukan Akhmad Faturohman Program Pasca Sarjana Magister Teknik Informatika Universitas Dian Nuswantoro Semarang yang berjudul "Pengaruh Pengembangan Model Pembelajaran E-learning Terhadap Prestasi Belajar Mahasiswa Fakultas Kedokteran Universitas Muhammadiyah Semarang”. model pengembangan e-Learning merupakan alternatif yang memungkinkan untuk meningkatkan kualitas hasil pembelajaran di FK Unimus. Tujuan dari penelitian ini : 1) Menerapkan e-learning sebagai pendukung konvensional proses pembelajaran di Fakultas Kedokteran, Universitas Muhammadiyah Semarang (FK Unimus), (2) meningkatkan kualitas pembelajaran yang akan dioptimalkan dengan menerapkan e-learning di FK Unimus, dan (3) siswa FK Unimus mampu meningkatkan potensi diri dalam belajar proses melalui e-learning. Ini penelitian merupakan pendekatan penelitian tindakan untuk penelitian dan pengembangan (Penelitian dan Pengembangan), yaitu dengan merancang sebuah sistem informasi berbasis teknologi belajar melalui web portal e-Miring, yang diterapkan pada FK Unimus, dengan sampel 50 siswa. Hasil Penelitian: (1) Dengan menerapkan e-learning di FK Unimus sebagai alternatif dukungan pembelajaran konvensional untuk media dalam proses pembelajaran, (2) faktor pendukung 
pengembangan pembelajaran e-learning di FK Unimus yaitu (a) kemampuan untuk mengambil keuntungan dari dosen di bidang teknologi informasi dinilai oleh responden masih relatif buruk, bahwa tidak semua penggunaan fakultas teknologi informasi dalam pengelolaan pembelajaran, (b) desain e-learning model pembelajaran, dinilai responden masih belum begitu baik, terutama dalam hal jumlah belajar konten dan model evaluasi, (c) siswa pada umumnya telah cukup aktif memanfaatkan teknologi informasi dalam pembelajaran, dan (3) terdapat pengaruh yang signifikan ketersediaan fasilitas teknologi informasi, kemampuan dosen menggunakan teknologi informasi, desain e-learning model pembelajaran, dan keaktifan siswa menggunakan teknologi informasi untuk Prestasi FK Unimus belajar siswa, sebelumnya dalam belajar siswa pembelajaran konvensional hasil masih relatif rendah, sedangkan setelah menerapkan e-learning menjadi lebih siswa Prestasi meningkat. Dari hasil di atas penulis mengajukan rekomendasi berikut ( 1 ) Untuk pemimpin FK Unimus diharapkan dapat meningkatkan fasilitas teknologi informasi, baik hardware, software, dan kapasitas bandwidth internet yang cukup untuk memperlancar proses pembelajaran, (2) ada perlu ditingkatkan fakultas kapasitas untuk menggunakan teknologi informasi sehingga dapat mengelola dengan baik melalui portal pembelajaran dengan e-learning yang telah disediakan, (3) guru perlu mengarahkan siswa yang jelas tentang materi pelajaran yang dapat diakses melalui jaringan komputer (internet / Intranet). (4) diperlukan sinergi antara kepemimpinan FK Unimus, manajemen pembelajaran, teknologi informasi manajer FK Unimus, untuk mendapatkan model desain pembelajaran yang dapat meningkatkan prestasi belajar siswa, (5) diperlukan evaluasi lebih lanjut dari penggunaan teknologi informasi dalam pembelajaran[7].

8. Penelitian ini dilakukan Wawan Setiawan yang berjudul "Pembelajaran Berbasis ICT:Model E-Learning Menggunakan Opensource Moodle“.Dalam memenuhi kebutuhan masa depan, kita dituntut untuk terus melakukan perubahan positip termasuk di bidang pendidikan. Dalam mencermati perubahan yang terjadi, perlu adanya percepatan (acceleration) dalam proses pembelajaran, yang bermuara pada terciptanya pembelajaran menjadi lebih efektif, efisien, dan optimal. Disamping hal tersebut, diupayakan mahasiswa dapat lebih termotivasi dalam belajarnya, sehingga memiliki wawasan ke arah masa depan yang lebih luas. Salah satu alternatif yang dapat membantu mahasiswa untuk menambah wawasan dengan percepatan diantaranya melalui penerapan teknologi. Kehadiran teknologi internet telah memunculkan diantaranya sebuah bentuk baru dari pedagogy yaitu pembelajaran elektronik yang dikenal dengan e- 
learning. E-learning adalah model pembelajaran yang berbasis web (internet), sehingga dapat didefinisikan pula sebagai sebuah bentuk teknologi informasi yang diterapkan di bidang pendidikan. Penelitian ini mencoba mempelajari model e-learning yang dikembangkan dengan opensource moodle yang merupakan program unggulan FPMIPA UPI. Dari hasil pengkajian, dengan fleksibilitas dan kesederhanaan moodle, sangat dimungkinkan lembaga pendidikan untuk mengembangkan e-learning yang cukup handal. Secara umum ditunjukkan terdapat perubahan positif performansi mahasiswa dengan kehadiran dan pemberdayaan e-learning. Namun demikian penciptaan kurtur harus terus didorong diantaranya melalui kebijakan dan komitmen lembaga melalui upaya yang terus melengkapi dan menyempurnakan fasilitas yang optimal. Universitas Pendidikan Indonesia dalam rencana strategisnya telah menjadikan ICT sebagai kultur kehidupan kampus modern. Untuk mewujudkan cita-cita tersebut perlu dicermati beberapa hal antara lain : pemahaman yang utuh akan peran internet pada instruktur/dosen; perlu dipersiapkan instruktur yang lebih banyak waktunya untuk memfasilitasi diskusi, menjawab berbagai pertanyaan dan topik diskusi yang muncul; instruktur sebaiknya memiliki skill yang memadai kebutuhan sistem untuk dapat lebih mudah memanage keseluruhan konten basis internet; instruktur sebaiknya banyak melakukan berbagai penelitian dan pencarian database terkait materi untuk melakukan updating terhadap bahan ajar; dan secara konsisten dan rutin, instruktur sebaiknya melakukan review terhadap bahan ajar untuk menjamin berjalannya link yang ditampilkan pada bahan ajar[8].

9. Penelitian ini dilakukan Zyanuri dan Eko Marpanji yang berjudul "Penerapan E-Learning Moodle Untuk Pembelajaran Siswa Yang Melaksanakan Prakerin”. Penerapan E-Learning Moodle untuk Pembelajran Siswa yang Melaksanakan Prakerin. Penelitian ini bertujuan untuk: (1) mengembangkan e-learning memperbaiki alat reproduksi sinyal audio video CD (2) mengetahui kelayakan e-learning yang dihasilkan sebagai sumber belajar siswa, dan (3) mengungkap keefektifan e-learning terhadap pencapaian hasil belajar siswa kelas XI teknik elektronika SMK Negeri 5 Banjarmasin yang melaksanakan Prakerin.Jenis penelitian ini adalah Penelitian dan Pengembangan (R\&D). Hasil penelitian menunjukkan bahwa : (1) e-learning yang dikembangkan dengan LMS Moodle melalui tiga tahapan, yaitu : perencanaan, desain, dan pengembangan. E-learning menyajikan materi standar kompetensi memperbaiki alat reproduksi sinyal audio video CD untuk siswa kelas XI Teknik Elektronika yang sedang melaksanakan Prakerin, (2) e-learning tersebut layak digunakan pada siswa kelas XI Teknik Elektronika SMK N 5 
Banjarmasin yang melaksanakan Prakerin. Kelayakan e-learning berdasarkan ahli materi termasuk katogori baik dengan skor rerata 3,98, berdasarkan ahli media termasuk katogori baik dengan skor rerata 3,90 berdasarkan uji beta termasuk kategori sangat baik dengan skor rerata 4,15, dan berdasarkan uji produk termasuk kategori baik dengan skor rerata 3,90, (3) Penggunaan elearning untuk siswa kelas XI Teknik Elektronika SMK Negeri 5 Banjarmasin yang melaksanakan Prakerin efektif meningkatkan hasil belajar kognitif siswa. Hal ini terbukti dengan perbedaan skor peningkatan pretest ke posttest untuk kedua kelas tersebut sebesar 13,24[9].

10. Penelitian ini dilakukan B. Lena Nuryanti yang berjudul " Model Pembelajaran E-Learning Melalui Homepage Sebagai Media Pembelajaran Sehingga Diharapkan Dapat Meningkatkan Minat Dan Kreativitas Siswa”. Pelaksanaan proses belajar mengajar untuk mengaktifkan belajar siswa memang tidak mudah, karena dalam setiap metode pembelajaran pasti ada beberapa hambatan. Salah satu hambatan yang dihadapi guru adalah kurangnya minat belajar dari mahasiswa sehingga mahasiswa menjadi malas dan jenuh dalam kegiatan belajar mengajar, sehingga guru seringkali mengalami kesulitan dalam merangsang kreativitas dan minat belajar. Penggunaan multi model pembelajaran dan multi media dapat dijadikan altematif yang dilakukan untuk merangsang kreativitas dan minat belajar mahasiswa, salah satunya dengan melaksanakan model pembelajaran e-learning dengan menggunakan homepage sebagai media pembelajarannya. Penelitian ini dilakukan untuk melihat hubungan model pembelajaran e-learning melalui homepage sebagai media pembelajaran kaitannya dalam meningkatkan kreativitas dan minat belajar mahasiswa. Populasi dalam penelitian ini adalah mahasiswa Program Pendidikan Tata Niaga Angkatan 2003 dan 2004[10].

Dari sepuluh Literature Review yang ada, telah dilakukan penelitian mengenai proses pembelajaran, disamping itu juga telah ada pembahasan mengenai hambatan belajar dalam pendidikan jarak jauh, teknologi informasi dan komunikasi sebagai proses pembelajaran, meningkatkan mutu pembelajaran dengan menggunakan elearning, e-learning adaptif berbasis karakteristik, perancangan e-learning berbasis pakar PHP dan MYSQL sebagai bahan belajar mandiri, namun demikian dapat disimpulkan pula secara keseluruhan bahwa secara khusus belum ada pembahasan seputar masalah yang menangani proses pembelajaran iLearning dalam dunia pendidikan. 


\section{PEMECAHAN MASALAH}

Untuk mengatasi berbagai permasalahan di atas. Dunia pendidikan memerlukan metode pembelajaran yang dapat mempermudah pelajar dalam mengembangkan kreativitas dan dapat berfikir secara kritis, cara belajar yang praktis, menyenangkan atau tidak membosankan dan dapat membangkitkan semangat pelajar dalam belajar, mempermudah pelajar dalam menaruh atau mencari berbagai kebutuhan dalam pembelajaran dan metode pembelajaran yang selalu berhubungan dengan kehidupan sehari-hari atau tidak terpisah dalam kehidupan sehari-hari dapat mengatasi masalah pemerataan akses pendidikan.

Sebuah metode pembelajaran yang memiliki fasilitas memadai kebutuhan dalam pembelajaran yaitu sebuah metode pembelajaran baru yang bernama iLearning. Dengan menggunakan metode pembelajaran iLearning ini dapat menunjang dalam proses belajar mengajar. Salah satu media yang menyediakan berbagai aplikasi untuk pembelajaran iLearning yaitu iPad. Karena iPad memiliki aplikasi atau fitur-fitur yang cukup lengkap untuk metode iLearning. Metode iLearning memiliki beberapa komponen yaitu:

1. Memiliki bahan informasi yang menarik perhatian dalam proses pembelajaran. Menggunakan gambar berwarna warni, dan selain itu proses pembelajaran menggunakan animasi, video, dan lagu atau nada. Perkembangan pembelajaran menggunakan iLearning terlihat lebih komunikatif dan menarik.

1) Gambar adalah tiruan barang atau visual seperti orang, binatang, tumbuhan, benda dan lain lain, coretan yang dibuat menggunakan pensil atau bisa menggunakan pointer mouse yang terdapat pada program menggambar di komputer. Bisa melakukan coretan pada dinding, lembaran kayu, atau bisa juga dilakukan pada kanvas imaginer di dalam program menggambar yang terdapat pada komputer.

2) Beberapa pengertian animasi menurut para ahli :

Menurut Vaughan (2004), animasi adalah usaha untuk membuat presentasi statis menjadi hidup. Animasi merupakan perubahan visual sepanjang waktu yang memberi kekuatan besar pada proyek multimedia dan halaman web yang dibuat. Banyak aplikasi multimedia menyediakan fasilitas animasi (Iwan Binanto, Multimedia Digital Dasar Teori + Pengembangannya, 2010) 
Animasi adalah gambar-gambar yang bergerak dengan kecepatan, arah, dan cara tertentu (Budi Sutedjo Dharmo Oetomo, S.Kom., MM, Perencanaan \& Pembangunan Sistem Informasi, 2006)

3) Video adalah suatu teknologi yang berfungsi untuk menangkap, merekam, menstransmisikan, memproses dan menata ulang gambar bergerak biasanya menggunakan sinyal elektronik atau menggunakan media digital, dan dapat menggunakan film seluloid. Yang berkaitan dengan penglihatan dan pendengaran. Video bisa juga disebut sebagai gabungan gambargambar mati yang dibaca secara berurutan dalam suatu waktu dengan kecepatan tertentu gambar-gambar yang digabung tersebut dinamakan frame rate.

4) Lagu adalah seni nada atau suara yang berurut, memiliki kombinasi, dan hubungan temporal biasanya diiringi dengan menggunakan alat musik, untuk menghasilkan irama musik yang mempunyai kesinambungan yang mengandung irama dan memiliki kesatuan. Ragam suara atua nada yang berirama disebut juga dengan lagu.

2. Memiliki materi atau teori sebagai bahan pembelajaran, menggunakan iLearning mahasiswa mudah mencari bahan matakuliah atau topik-topik pelajaran yang dibutuhkan yang tersimpan dalam aplikasi yang bernama e-book. E-book adalah singkatan dari Electronic Book atau buku elektronik. E-book tidak lain adalah sebuah bentuk buku yang dapat dibuka secara elektronis melalui komputer. E-book ini berupa file dengan format bermacam-macam, ada yang berupa pdf (portable document format) yang dapat dibuka dengan program Acrobat Reader atau sejenisnya. Ada juga yang dengan bentuk format htm, yang dapat dibuka dengan browsing atau internet eksplorer secara offline. Ada juga yang berbentuk format exe. Pada kebanyakan e-book menggunakan bentuk format pdf. Karena lebih mudah dalam mempergunakannya dan mudah dalam mengolah security.

3. Quiz dan evaluasi pembelajaran menjadi lebih terbuka karena dapat dilakukan dimana pun, selain itu dapat dilakukan saat belajar mengajar berlangsung.

4. Latihan soal yang di berikan sesuai materi yang diberikan oleh pengajar.

5. Simulasi pembelajaran menggunakan iLearning, teori dan perumusan materi dapat dijelaskan secara menarik dan cukup kompleks.

6. Diskusi kelompok dapat dilakukan dimana saja, dan waktunya kapan saja menjadi lebih mudah.

7. Tanya jawab atau interaksi dapat dilakukan secara langsung atau tidak langsung dengan menggunakan forum yang terdapat pada aplikasi iLearning di ipad. 
Istilah iLearning mengandung pengertian yang sangat luas adalah sistem pendidikan yang menggunakan aplikasi elektronik untuk mendukung belajar mengajar dengan media internet, jaringan komputer, maupun komputer standalone dan dapat dilakukan kapan waktupun saat senang, kapan waktupun saat sedang belajar, lebih banyak have funnya, lebih banyak belajarnya, memadukan kehidupan dengan pembelajaran tidak lagi terpisah-pisah. iLearning itu 4B, yang di maksud dengan 4B adalah Belajar, Bermain, Berdoa, dan Bekerja.

\section{Belajar}

Belajar menurut kamus besar Indonesia adalah berusaha memperoleh kepandaian atau ilmu, berlatih, berubah tingkah laku atau tanggapan yang disebabkan oleh pengalaman. Dan pengertian belajar menurut beberapa para ahli :

Menurut Slameto (2010: 2) belajar adalah suatu proses usaha yang dilakukan seseorang untuk memperoleh suatu perubahan tingkah laku yang baru secara keseluruhan sebagai hasil pengalaman sendiri dalam berinteraksi dalam lingkungan dan berusaha memperoleh kepandaian, ilmu, berlatih, atau tanggapan perubahan tersebut ditampakkan dalam bentuk peningkatan kualitas dan kuantitas tingkah laku seperti peningkatan kecakapan, pengetahuan, sikap, kebiasaan, pemahaman, ketrampilan, daya pikir, dan kemampuan-kemampuan yang lain.

Menurut Moh.Surya (1981:32) belajar adalah Suatu proses usaha yang dilakukan individu untuk memperoleh suatu perubahan tingkah laku yang baru keseluruhan, sebagai hasil pengalaman individu itu sendiri dalam interaksinya dengan lingkungan. Kesimpulan yang bisa diambil dari kedua pengertian di atas, bahwa pada prinsipnya, belajar adalah perubahan dari diri seseorang.

Robert M. Gagne dalam buku: the conditioning of learning mengemukakan bahwa: Learning is change in human disposition or capacity, wich persists over a period time, and which is not simply ascribable to process a groeth. Belajar adalah perubahan yang terjadi dalam kemampuan manusia setelah belajar secara terus menerus, bukan hanya disebabkan karena proses pertumbuhan saja. Gagne berkeyakinan bahwa belajar dipengaruhi oleh faktor dari luar diri dan faktor dalm diri dan keduanya saling berinteraksi.

\section{Bermain}

Kegiatan bermain merupakan kegiatan yang diperlukan oleh setiap manusia tanpa memandang usia. Kegiatan bermain merupakan suatu kegiatan yang bersifat sangat penting, sebab melalui potensi yang dimiliki manusia dapat tergali secara 
optimal. Kegiatan bermain dapat memberikan manfaat dalam bidang pendidikan, bermain untuk dapat menemukan bagaimana cara memasuki dunia mereka, mengatasi tugas-tugas hidup, menguasai permainan baru, dan memperoleh kepercayaan diri untuk tumbuh menjadi orang yang berguna. Definisi bermain dikemukakan oleh beberapa ahli antara lain sebagai berikut :

Menurut M. As'adi (2009: 26) bermain adalah kegiatan yang tidak memiliki suatu peraturan lain kecuali yang ditetapkan pemain, dan seseorang yang melakukan kegiatan bersenang - senang, bermain adalah salah satu kegiatan yang menghibur, dapat melepaskan masalah sejenak. Bermain juga dapat meningkatkan motivasi belajar, memberikan penguatan atas kompetensi yang sudah dikuasi pelajar yang menekankan pada pengembangan, penguatan, dan kreatifitas. Ciri : ada penjelasan, menarik, ada hubungan sebab dan akibat, ada ringkasan dan hiburan.

Menurut Tjandrasa (2001:320) mengemukakan bahwa “Bermain adalah setiap kegiatan yang dilakukan karena kesenangan yang ditimbulkannya, tanpa mempertimbangkan hasil akhir, bermain dilakukan secara sukarela dan tanpa paksaan atau paksaan dan luar kewajiban”.

Menurut Karl Buhier dan Schenk Danziger (2001:45) mengemukakan bahwa "Bermain adalah kegiatan yang menimbulkan "kenikmatan”, dan kenikmatan itu menjadi rangsangan bagi perilaku lainnya.

\section{Berdoa}

Do’a menurut Kamus Besar Bahasa Indonesia berarti permohonan (harapan, pujian) kepada Tuhan; Sebagai manusia beragama, berdo’a tentunya menjadi salah satu ritual rutin sebagai bentuk pengabdian dan permohonan kepada Sang Khalik. Berdoa adalah permohonan kepada Sang Pencipta yang disertai kerendahan hati untuk mendapatkan suatu kebaikan dan keselamatan yang berada di sisi-Nya. Sedangkan sikap khusyu' dan tadharru' dalam menghadapkan diri kepada-Nya merupakan hakikat pernyataan seseorang yang sedang mengharapkan tercapainya sesuatu yang dimohonkan. Contoh berdoa kepada Sang Pencipta seperti meminta keselamatan hidup, rezeki yang halal dan keteguhan iman. Sebaiknya kita berdo’a kepada Sang Pencipta setiap saat karena akan selalu didengar olehNya.

\section{Bekerja}

Bekerja adalah melakukan sesuatu pekerjaan (perbuatan) atau sesuatu yang dikeluarkan oleh seseorang sebagai profesi, yang sengaja dilakukan untuk dapat 
memenuhi kebutuhan hidup mendapatkan penghasilan dan memiliki ekonomi yang mapan. Pengeluaran energi untuk kegiatan yang dibutuhkan oleh seseorang untuk mencapai tujuan tertentu dan kegiatan ini dilakukan secara rutin dalam suatu pekerjaan. Kegiatan yang dilakukan karena adanya dorongan dan memiliki rasa tanggung jawab yang besar terhadap profesi yang dijalani. Kegiatan yang dilakukan karena adanya unsur kesengajaan dan terencana, dan karena adanya tujuan yang utama. Yang menghasilkan suatu karya.

iLearning dirancang secara cermat sebagai metode pembelajaran elektronik yang dapat meningkatkan kadar interaksi dalam proses belajar, antara pengajar dan pelajar, antara sesama pelajar ataupun antara pelajar dengan bahan ajar. iLearning juga dapat dilakukan dimana saja dan kapan saja waktunya, sumber pembelajaran yang dikemas secara elektronik dan dapat diakses oleh pelajar melalui internet, maka pelajar dapat melakukan interaksi dengan sumber pembelajaran yang dapat diakses kapan saja dan dari mana saja, demikian juga dengan tugas- tugas kegiatan pembelajaran, dapat diserahkan kepada pengajar begitu tugas telah selesai dikerjakan.

Dengan Fleksibilitas waktu dan tempat, jumlah peserta pelajar dapat dijangkau melalui kegiatan pembelajaran elektronik menggunakan iLearning semakin banyak dan meluas. Ruang dan waktu tidak lagi menjadi hambatan dapat dilakukan oleh siapa saja, dimana saja, dan kapan saja, seseorang dapat belajar, kesempatan belajar terbuka lebar bagi siapa saja yang membutuhkannya. Fasilitas yang tersedia dalam iLearning dapat membantu mempermudah penyempurnaan dan pengembangan bahan ajar elektronik.

\section{Distribusi E-learning dalam iLearning}

Pembelajaran iLearning diklasifikasikan menjadi 2 kelompok yaitu belajar tetap dan belajar dinamis. Belajar tetap. Pengguna sistem bisa mendownload bahan pembelajaran yang dibutuhkan hanya (isinya). Dimana administrator dapat mengapload file-file bahannya saja. Situasi pembelajaran secara aktual seperti komunikasi tidak ada dalam sistem ini. Sistem ini berguna untuk orang-orang yang bisa belajar mandiri dari bahan-bahan bacaan yang disediakan dalam bentuk HTML, power point, PDF, atau video. Jika digunakan sistem dapat secara fungsional mendukung kegiatan belajar mengajar yang dilakukan secara tatap muka di dalam kelas.

Pembelajaran dinamis. Fasilitas yang ditawarkan lebih bervariasi dari sistem yang pertama disebutkan. Fasilitasnya seperti forum diskusi, chatting, e-mail, evaluasi 
belajar, para pegguna dan bahan elekronik yang tersedia. Hal ini memungkinkan para pelajar untuk belajar di dalam lingkungan yang produktif seperti di dalam kelas. Tidak ada lagi instruktur yang aktif memberikan bahan ajar atau meminta pelajar untuk bertanya tentang pelajaran yang tidak dipahami, tetapi disini pelajar dilatih untuk belajar secara aktif dan kritis. Sistem belajar e-learning bisa dikembangkan untuk belajar bersama dengan metode yang mendekati belajar kerjasama atau belajar dari proses pemecahan masalah yang di berikan (belajar berdasarkan permasalahan).

Hubungan antara kondisi pembelajaran dan fasilitas yang tepat dapat dilihat pada tabel di bawah ini (diadopsi dari Distance Learning dan Sun Microsystems):

Tabel 1. Perbandingan Distance learning

\begin{tabular}{|c|c|c|}
\hline & $\begin{array}{l}\text { Same Time (Synchronous) } \\
\text { (Waktu yang sama) }\end{array}$ & $\begin{array}{l}\text { Different Time (Asynchronous) } \\
\text { (Waktu yang berbeda) }\end{array}$ \\
\hline $\begin{array}{c}\text { Same Place } \\
\text { (Tempat yang sama) } \\
\\
\text { Different Place } \\
\text { (Tempat yang berbeda) }\end{array}$ & $\begin{array}{l}\text { Ruang Kelas } \\
\\
\text { Audio Conferencing } \\
\text { Video Conferencing } \\
\text { Satelite Delevery } \\
\text { Chatting Room } \\
\text { Instrutor -led } \\
\text { (Synchronous Learning System) } \\
\text { Synchronous Steaming }\end{array}$ & $\begin{array}{l}\text { Pusat Belajar } \\
\text { Laboraturium } \\
\text { Perpustakaan } \\
\text { www } \\
\text { E-Learning System } \\
\text { Video tape/ Audio tape } \\
\text { CD-ROM } \\
\text { Archived Streamed } \\
\text { Video } \\
\text { Email/Listserv }\end{array}$ \\
\hline
\end{tabular}

Ada e-learning standardisasi yang harus digunakan sebagai acuan pengembangan sistem pembelajaran iLearning diantaranya adalah LSTC, IMS, dan ADL.

LTSC dibuat oleh Institute of Electrical and Electronic Engineers (IEEE) yang telah banyak menciptakan standar teknologi untuk teknologi informasi dan ilmu pengetahuan. Tujuan LSC adalah untuk membentuk akreditasi standar secara elektronik memberikan pelatihan, saran, dan yang berkaitan dengan teknologi belajar.

Sedangkan IMS adalah sebuah organisasi penting dalam pembelajaran elektronik. Persetujuan antara lembaga akademis, perusahaan dan pemerintah untuk membangun dan mendukung spesifikasi terbuka untuk mempelajari cara pembagiannya dan pengembangan isinya dan juga penambahan pelajar diantara sistem yang berbeda.

ADL menciptakan Courseware Object Reference Model (SCORM). SCORM adalah spesifikasi standar untuk bisa dimanfaatkan kembali dan bisa dioperasikan lagi dari isi pembelajaran tersebut [13]. 


\section{iLearning Design system}

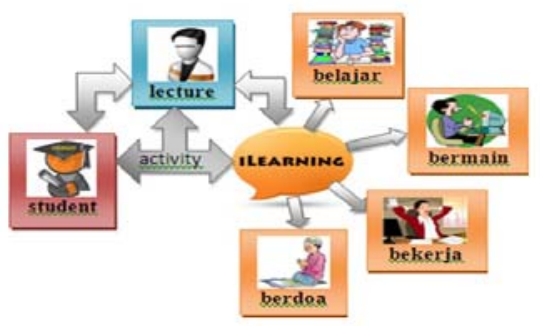

Gambar 1. iLearning Design System

Dari gambar 1 di atas bisa dilihat metode yang menggunakan iLearning ini dapat digunakan dalam kehidupan sehari-hari, aktivitas atau kegiatan yang sering dilakukan. Misalnya saat belajar, saat bermain, saat bekerja, dan saat berdoa yang saling berkaitan.

\section{iLearning Arsitektur}

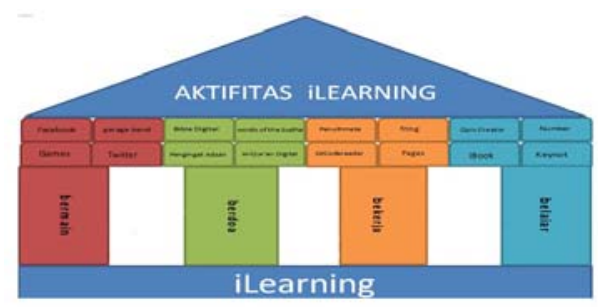

Arsitektur 1. iLearning Arsitektur

Dari arsitektur 1 di atas bisa dilihat aktifitas iLearning ini memiliki banyak aplikasi yang mempermudah proses pembelajaran, yang tidak dapat terpisahkan dalam kehidupan sehari-hari. Aplikasi yang dapat menunjang belajar yaitu iBook, Keynot, Number, Quis Creator. Kemudian bisa juga bekerja aplikasinya adalah Pages, Fring, QrCodereader, Penultimate. Aplikasi yang digunakan untuk berdoa yaitu Bible Digital, World of the Budha, PengingatAdzan, Al-Qur'an Digital. Bermain adalah salah satu bagian dari metode pembelajaran iLearning aplikasi yang menunjang bermain yaitu Facebook, Twitter, Game center, dan Gerage Band. 


\section{IMPLEMENTASI}

Salah satu cara pembelajaran dengan menggunakan metode iLearning yaitu 4B (belajar, bermain, bekerja, dan berdoa) adalah dengan menggunakan iPad karena iPad memiliki standarisasi metode pembelajaran iLearning yaitu dengan menggunakan aplikasi iBook, Quiz Creator, Number, Keynote, Cram, Formula. Aplikasi yang digunakan untuk bekerja Penultimate, QrCodereader, Fring, Pages. Adapun aplikasi yang digunakan sebagai ibadah atau berdoa Bible Digital, World of the Budha, Pengingat Adzan, Al-Qur'an Digital. Aplikai pendukung untuk bermain yang terdapat pada iPad adalah Facebook, Garage Band, Game Center, dan Twitter.

\section{Belajar}

\section{iBook}

iBook adalah singkatan dari electronic book atau buku elektronik. iBook tidak lain adalah sebuah bentuk buku yang dapat dibuka secara elektronis melalui komputer. iBook ini berupa file dengan format bermacam-macam, ada yang berupa pdf ( portable document format ) yang dapat dibuka dengan program acrobat reader atau sejenisnya. Ada juga yang bentuk format html, yang di buka dengan browsing atau internet eksplorer secara offline.

\section{Quis Creator}

Aplikasi Quis Creator ini memungkinkan pengguna untuk menciptakan kuis, tes, atau ujian menggunakan perangkat iPad. Hal ini memungkinkan pengajar untuk membuat kuis online dan meminta peserta didik untuk memuat tes dan mengambil kuis dan mengirim hasilnya kembali. Hal ini juga mendorong kuis berbagi antara pengguna online.

\section{Number}

Number adalah satu aplikasi yang terdapat pada iPad kegunaan number ini bisa dipakai untuk membuat spreadsheet atau dokumen Excel. 


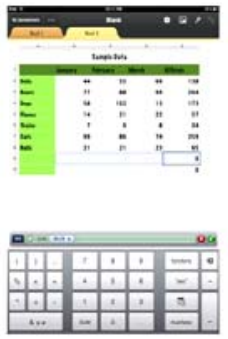

Prototype 1. Aplikasi Number untuk iLearning

\section{Keynote}

Keynote adalah aplikasi presentasi dengan kemampuan yang jauh lebih baik dan lebih mudah digunakan dibandingkan Power Point dengan fitur export dan import file Power Point.

\section{Bekerja}

\section{Penultimate}

Dengan Penultimate yang membantu anda untuk menulis dengan jari anda secara cepat sehingga anda dapat mengikuti percakapan dengan tulisan tangan cepat, dan anda dapat langsung mengirimkan catatan tersebut dengan email. Penerima email anda membaca tulisan tangan anda.

\section{QrCodereader}

QrCodereader adalah suatu jenis kode matriks atau kode batang dua dimensi, dapat dengan mudah dibaca oleh pemindai QR merupakan singkatan dari quick response atau respons cepat, yang sesuai dengan tujuannya adalah untuk menyampaikan informasi dengan cepat dan mendapatkan respons yang cepat pula. Berbeda dengan kode batang, yang hanya menyimpan informasi secara horizontal, kode QR mampu menyimpan informasi secara horizontal dan vertikal, oleh karena itu secara otomatis kode QR dapat menampung informasi yang lebih banyak daripada kode batang. Berfungsi bagaikan hipertaut fisik yang dapat menyimpan alamat dan URL, nomer telepon, teks dan sms yang dapat digunakan pada majalah, iklan, pada tanda-tanda bus, kartu nama ataupun media lainnya. Atau dengan kata lain sebagai penghubung secara cepat konten daring dan konten luring. 


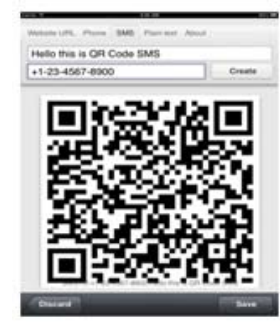

Prototype 2. Aplikasi QrCodereader untuk iLearning

\section{Fring}

Fring Merupakan aplikasi untuk telepon selular melalui koneksi internet yang berbasis pada web yang mendukung layanan telepon, pengiriman pedan instan yahoo! Messenger, skype, google, facebok, twiter. Kali ini fring meluncurkan aplikasi yang dapat melakukan chat video secara group.

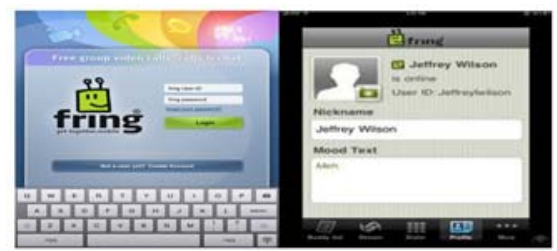

Prototype 3. Aplikasi Fring untuk iLearning

\section{Pages}

Pages adalah suatu aplikasi yang terdapat pada iPad. Anda dapat mendownload artikel-artikel apa saja, menyimpan dan membacanya saat anda berada di mana saja, sehingga tidak ada waktu yang terbuang, kemana saja, anda sedang menambah pengetahuan anda. Offline Pages membantu anda menampilkan bahan-bahan yang sudah di simpan untuk dibaca kembali.

\section{Berdoa}

\section{Bible Digital}

Aplikasi Bible Digital yang terdapat pada iPad ini berisikan tentang bookmarks pencarian dan penjelasan sejarah tentang alkitab. 


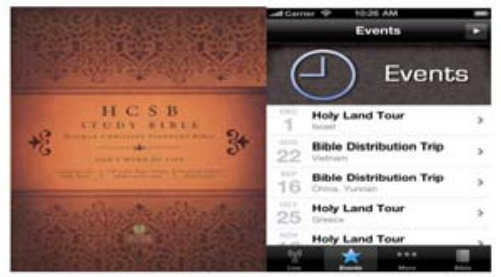

Prototype 4. Aplikasi Bible Digital untuk iLearning

\section{World of the Budha}

World of the Budha merupakan aplikasi yang berisi tentang perjalanan agama budha, dalam aplikasi ini, banyak terdapat kutipan, yaitu 170 kutipan tentang agama budha yang dapat mengubah pandangan hidup tentang dunia.

\section{Pengingat Adzan}

Pengingat Adzan adalah aplikasi yang berfungsi untuk mengingatkan waktu sholat.

\section{Al-Qur'an Digital}

Al-qur'an digital adalah software yang berisi database al-Qur'an baik teks ayat-ayat arabnya maupun terjemahan kebahasa lainnya, gambar, maupun suara hasil bacaan ayat-ayatnya. Dengan al-Qur'an Digital para penggunanya dapat mencari apa pun yang berhubungan dengan al-Qur' an secara mudah dan cepat.

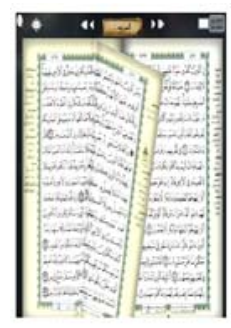

Prototype 5. Aplikasi Al-Qur'an Digital untuk iLearning

\section{Bermain}

\section{Facebook}

Facebook adalah situs jaringan sosial dimana penggunanya bisa saling berinteraksi, kirim mengirim pesan, bertemu dan memelihara persahabatan dengan 
teman lama, mencari teman baru, chating, bermain bersama, berbagi file dan foto, mencari partner bisnis (melancarkan bisnis atau promosi).

\section{Garage Band}

Aplikasi garage band ini merupakan aplikasi musik yang biasa digunakan oleh musisi untuk membuat lagu dan komposisi musik yang ada. Aplikasi ini memiliki beberapa fitur yaitu touch - to - play, guitar amps dan effects, 8 track perekaman, dan mixing- mixing.

\section{Twitter}

Twitter adalah sebuah platform blogging mikro yang mengundang pengguna untuk menjawab pertanyaan. Twitter juga merupakan layanan pesan yang memungkinkan pengguna untuk menanggapi update status pengguna lain. Selain itu, twitter juga memungkinkan pengguna untuk mengakses lokal, nasional dan dunia real-time kejadian di dunia berita serta update sederhana dari teman-teman.

\section{Game Center}

Game Center merupakan bagian dari bermain atau permainan. Games penting untuk perkembangan otak, untuk meningkatkan konsentrasi dan melatih untuk memecahkan masalah dengan tepat dan cepat.

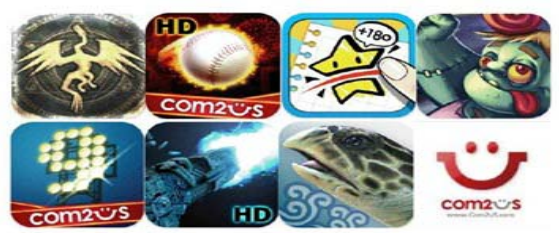

Prototype 6. Aplikasi Game Center untuk iLearning

\section{KELEBIHAN DAN KELEMAHAN PEMBELAJARAN ILEARNING}

Mengetahui kelebihan dan kelemahan iLearning dapat menentukan keputusan seorang pengajar untuk mengimplementasikan sistem iLearning dalam pembelajaran. Berikut ini diuraikan sepuluh kelebihan yang dimiliki iLearning dan empat kelemahan sistem iLearning. Dengan memahaminya dapat mendorong pengajar secara efektif dan efisien dengan mengambil keuntungan dari kelebihan dan menambal kelemahannya. 
Penguraian dari kelebihan yang dimiliki iLearning yaitu:

1) proses pembelajaran iLearning dapat dilakukan dimana saja dan kapan saja tidak terbatas;

2) waktu dan biaya tidak terlalu terbuang banyak atau mengefesiensikan waktu dan biaya;

3) pembelajar dapat memilih materi pembelajaran sesuai dengan level pengetahuan dan interestnya;

4) keberhasilan menyelesaikan pembelajaran secara online mampu membangun kemampuan belajar mandiri dan kepercayaan diri pembelajar;

5) mendorong pembelajar untuk lebih bertanggung jawab dalam belajar;

6) kemampuan pelajar untuk daya belajar efektif study independent;

7) pelajar dapat mengembangkan diri atau melakukan penelitian guna meningkatkan wawasan;

8) dapat mengatasi keterbatasan ruang dan waktu;

9) penghematan kertas karena penggunaan textbook berbentuk online ini dapat mengurangi global warming;

10) mempermudah mahasiswa dalam menyimpan atau mengambil materi pembelajaran karena lebih terstruktur yaitu dengan menyimpannya di rak buku online; dan

11) mampu memfasilitasi dan menerapkan gaya belajar yang berbeda melalui beragam aktivitas dan fleksibelitas untuk bergabung dalam forum diskusi setiap saat.

iLearning selain memiliki kelebihan metode ini juga memiliki kelemahan diantaranya yaitu:

1) beberapa matakuliah bisa saja sulit direalisasikan dalam bentuk iLearning;

2) pembelajaran yang harus menyediakan waktu untuk mempelajari aplikasi iLearning sehingga dapat mengganggu bobot kredit mata kuliah;

3) kurangnya tenaga profesional yang memiliki keterampilan dalam hal pembelajaran iLearning dengan menggunakan iPad; dan

4) peserta didik yang tidak familiar dengan struktur software pendukung iLearning akan tertinggal dari teman sekelasnya.

\section{KESIMPULAN}

iLearning yang terdapat pada artikel ini dapat menciptakan pembelajaran yang mandiri dan interaktif dalam kehidupan sehari-hari dan dapat memecahkan masalah 
dalam akses pembelajaran. iLearning mengorganisir aktifitas peserta didik untuk bisa berkesinambungan dengan belajar, bermain, berdoa dan bekerja. Diharapkan pengembangan iLearning dapat meningkatkan mutu pendidikan, dapat memberikan solusi permasalahan pembelajaran dalam komunikasi dan informasi, pemerataan kesempatan belajar, dapat menciptakan integritas yang baik untuk sistem pembelajaran modern di masa depan dan dapat meningkatkan sumber daya manusia. Dengan demikian iLearning merupakan leaders yang baik untuk pendidik maupun peserta didik untuk mendapatkan informasi yang akurat dan relevant yang bisa di dapat dimana saja, kapan saja disaat kita belajar, bermain, berdoa maupun bekerja. Melakukan 4B hanya dengan satu sentuhan tangan.

\section{DAFTAR PUSTAKA}

[1] Nurhadi. 2010. Pengembangan E-Learning Pembelajaran Pendidikan Kewarganegaraan untuk Sekolah Lanjutan Tingkat Atas (SLTA). Yogyakarta: Universitas Negeri Yogyakarta pp. 1-2

[2] K.Yuli. 2010. Teknologi Informasi Dan Komunikasi Dalam Proses Pembelajaran. Diakses pada tanggal 19 November 2011 dari www.bpkpenabur.or.id

[3] Tafiardi. 2005. Meningkatkan Mutu Pendidikan Melalui E-learning. Jakarta:Universitas Negeri Jakarta. pp. 28-30

[4] Y. Rizka. 2011. Perancangan E-learning Berbasis Pakar PHP Dan MYSQL. Jakarta:Universitas Islam Negeri. pp. 13-15

[5] H. Kuswari. 2011. E-Learning Adaptif Berbasis Karakteristik Peserta Didik. Yogyakarta: Fakultas MIPA, Universitas Negeri Yogyakarta. pp. 32-33

[6] Wiwin Kuswinardi. Jacobus. 2009. Pengembangan Sistem Konten Elektronic Book Terpadu Untuk Media Pembelajaran Berbasis Web. Malang: Fakultas Teknologi Informasi, Universitas Kanjuruhan Malang. pp. 9

[7] Faturohman. Akhmad. 2011. Pengaruh Pengembangan Model Pembelajaran E-Learning Terhadap Prestasi Belajar Mahasiswa Fakultas Kedokteran Universitas Muhammadiyah Semarang. Semarang: Magister Teknik Informatika, Universitas Dian Nuswantoro Semarang. pp. 2

[8] Setiawan. Wawan. 2006. Pembelajaran Berbasis ICT: Model E-Learning Menggunakan Opensource Moodle. Diakses pada tanggal 19 November 2011 dari jurnal.upi.edu 
[9] Marpanji. Eko, Zyanuri. 2012. Penerapan E-Learning Moodle Untuk Pembelajaran Siswa yang Melaksanakan Prakerin. Yogyakarta: Fakultas Teknik, Universitas Negeri Yogyakarta. pp.

[10] Nuryanti Lena. B. 2004. Model Pembelajaran E-Learning Melalui Homepage Sebagai Media Pembelajaran Sehingga Diharapkan Dapat Meningkatkan Minat Dan Kreativitas Siswa. Diakses pada tanggal 19 November 2011 dari jurnal.upi.edu

[11] Iwan Binanto. 2010. Multimedia Digital Dasar Teori + Pengembangannya. Andi Offset. Yogyakarta.

[12] Budi Sutedjo Dharmo Oetomo, S.Kom., MM. 2006. Perencanaan \& Pembangunan Sistem Informasi. Andi Offset. Yogyakarta

[13] S. B. Renaldy, dkk. 2010. Ilmu Implementasi Dengan Sistem E-Learning Untuk Pembelajaran Jarak Jauh Di Indonesia. Tangerang: Perguruan Tinggi Raharja. pp. 55-56

[14] Siahaan. 2002. Pengguna Bahan Ajar Multimedia Berbasis Web. Diakses pada tanggal 28 Desember 2011 dari odink.wordpress.com [15] Slameto. 2010. Penerapan Pembelajaran Berbasis Komputer Model Drill Untuk Meningkatkan Prestasi Belajar Siswa Pada Materi Fungsi Program Aplikasi Pengolah Kata Dalam Mata Pelajaran Teknologi Informasi Dan Komunikasi. Diakses pada tanggal 28 Desember 2011 dari repository.upi.edu/operator/upload/ s_ktp_0910113_chapter2.pdf

[16] Djamarah. 1996. Mengintegrasikan Blog Dalam Aktifitas Pembelajaran (Elearning). Diakses pada tanggal 28 Desember 2011 dari dianmanajemenpendidikan.blogspot.com

[17] M. As’adi. 2009. Permainan Dan Belajar Psikologi. Diakses pada tanggal 28 Desember 2011 dari belajarpsikologi.com/metode-permainan-dalampembelajaran/ 